\title{
高性能永久磁石モータの技術動向と応用
}

\author{
石橋利之 *
}

\section{Technology Trend of High Performance Permanent Magnet Motors and Their Applications}

\author{
Toshiyuki Ishibashi
}

\section{Synopsis}

Permanent magnet motor technology keeps improving because of the progress of the permanent magnet, the semiconductor device and the motor control technology. This article describes the technology trend of high performance permanent magnet motors and their applications.

Remarkably compact, light-weight and high performance permanent magnet motors were obtained by using a Nd-Fe-B permanent magnet. The performance of permanent magnet motor is correlated closely with the property of permanent magnet. The high density winding technique and the cooling method of molding with a heat-conductive resin are effective for down-sizing of motor. However, the high energy permanent magnet increases the cogging torque of motor. A magnetic field analysis is effective in reducing the cogging torque. The ultra-small-sized motors and the large torque motors are the recent topics.

Permanent magnet motors are widely used instead of induction motors or hydraulically-operated system. The inverter driven permanent magnet motors have enable industry facilities to realize higher performance and energy saving. The compact and flat-shaped permanent magnet motor removed a machine room from the elevators. The electric injection molding machines have brought about improving an energy conservation and a working environment. The industrial robots have flexible solutions for industrial automation, for practically all manufacturing and material handling requirement.

The improvement of the property, the quality and the reliability of the permanent magnet is expected for the permanent magnet motor.

\section{1.まえがき}

モータ技術は 100 年以上の歴史を有しており，理論的・ 原理的には完成されたと思われている．しかし，周辺技術 の進歩によって，モータ技術は今でも発展を続けている． 永久磁石モータは, 永久磁石の高性能化, 半導体デバイ スの性能向上,制御技術の進歩により急速に進化し続けて おり，広範囲に普及している。

本解説では，高度な制御により駆動される永久磁石モ一 タについて，光の技術動向と応用について述べる。

\section{2 . 各種モータの種類と特徵}

永久磁石モータは, 永久磁石の発生する磁石磁界を有効 に利用することから，小型・軽量化と高効率を実現してい
る.最近はリニアモータも普及し始めているが , ここでは 回転型モータを取り上げる。

\section{1 各種モータの比較}

モータには樣々な種類があるが, 高度な制御により駆動 するモータには, DC モータ, 誘導モータ, 同期モータな どがある .

DC モータ (直流モータ； DCM と略される) は, 歴史 的に最も古く，弚の制御性の良さから可変速モータとして 用いられている.しかし, 機械的な整流機構 (整流子とブ ラシ) があるためメンテナンスが必要で, 高速回転ができ ないため小型・軽量化で限界がある .

誘導モータ (誘導電動機; IM) は, 固定子巻線による 回転磁界と回転子速度の差 (すべり速度) により回転子の 二次導体に電圧か誘起し電流が流れトルクを発生する.構 
造が簡単で堅牢であり,比較的低コストでシステムを構築 することができ,インバータ駆動システムとしての完成度 も高い．しかし，すべりに比例した損失 (二次銅損) が回 転子に発生するため効率は高くない．

同期モータ (SM) である永久磁石モータ (PM モータ ; PMSM) は, 永久磁石を配置した回転子が, 固定子側の回 転磁界に吸引・反発し, 同期速度で回転する.永久磁石を 回転子表面に配置した表面磁石モータ(SPM モータ; SPMSM) では磁石トルクだけであるが，回転子内部に永 久磁石を埋め込んだ埋込磁石モータ(IPMモータ;IPMSM) では,リラクタンストルクも有効に利用するため，効率や トルク/電流特性を改善できる .

ただし，永久磁石モータは減磁の危険性を有している． 運転中の異常な加熱と過電流による印加磁界が同時に作 用したり，保磁力が異常に低いなど不適切な磁石を選んだ 場合には,搭載した磁石は減磁し，モータ特性が低下する ことが報告されている1).

同期モータ (SM) には,他にリラクタンスモータ (RM) であるスイッチトリラクタンスモータ (SRM) やシンク ロナスリラクタンスモータ (SynRM) がある .

各種モータの諸特性 2) をTable 1 に 効率特性 ${ }^{3)}$ を Fig.1

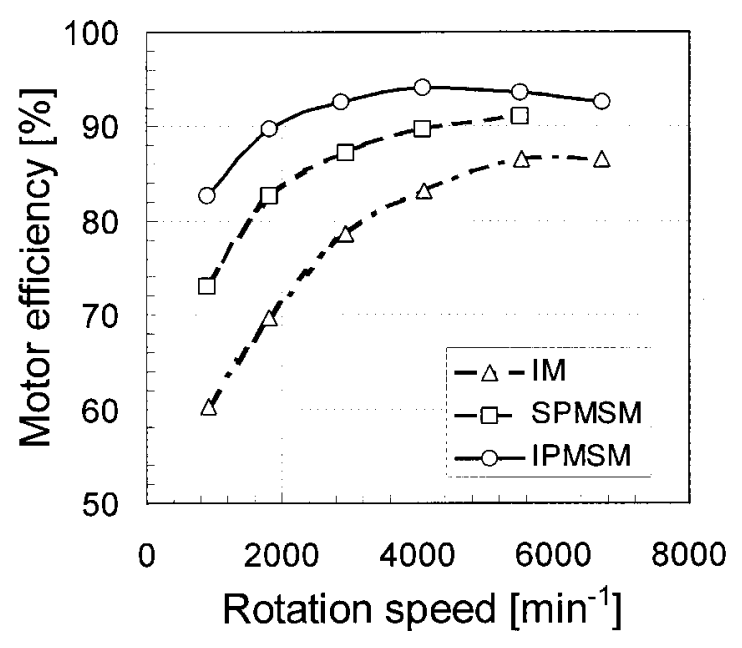

Fig.1. Variation of motor efficiency for various motors; induction motor(IM), surface permanent magnet synchronous motor(SPMSM), and interior permanent magnet synchronous motor(IPMSM).
に示した・最高回転数, 堅牢性, 信頼性の面では誘導モ一 タが, 効率, 軸出力, 制御性の面では永久磁石モータが適 していることが分かる.

\section{2 永久磁石モータの回転子構造}

永久磁石モータの回転子については,樣々な構造が提案 されている ${ }^{4)}$. 代表的な回転子構造をFig.2に示した。い ずれも 4 極に整理し直している.

Fig.2(a) のリング形状の永久磁石を回転子コアの表面に 配置するSPM 構造は，小型永久磁石モータで多く採用さ れている．ラジアル異方性または極異方性磁石が多いが， 極毎に分割した場合には直線異方性磁石が用いられるこ ともある。

Fig.2(b) は極毎に永久磁石か独立している SPM 構造で, 直線異方性磁石を用いることが多い.図のようにかまぼこ 形状の偏肉磁石を採用することもある．

大型永久磁石モータではIPM構造であることが多いが， 平板形状で直線異方性磁石をロータコアの内部に配置す る Fig.2(c)の構造が採用されることが多い．

\section{3 . 永久磁石モ一夕の技術動向}

産業用途などに用いられる永久磁石モータには, イン バータで駆動する高効率を指向する可変速ドライブもあ るが ここではより高度な制御が可能なサーボドライブ用 永久磁石モータであるサーボモータについて，弚の小型・ 高性能化, 超小型化, 大容量化について述べる.

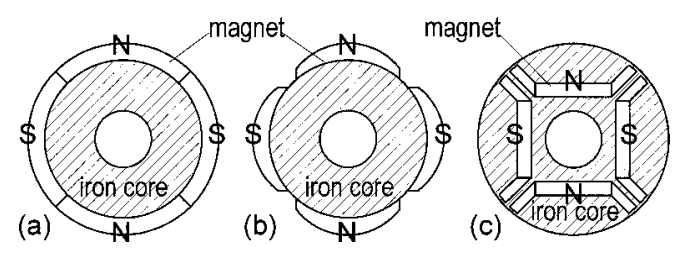

Fig.2. Typical rotor configurations of permanent magnet motors; (a) and (b); surface permanent magnet type(SPM), and (c); interior permanent magnet type (IPMSM).

Table 1. Comparison of various motors; DC motor(DCM), induction motor(IM), surface permanent magnet synchronous motor(SPMSM), interior permanent magnet synchronous motor(IPMSM), and switched reluctance motor(SRM).

\begin{tabular}{c|c|c|c|c|c}
\hline & DCM & IM & SPMSM & IPMSM & SRM \\
\hline max. efficiency [\%] & $85 \sim 89$ & $94 \sim 95$ & $85 \sim 97$ & $95 \sim 97$ & $<90$ \\
\hline efficiency [\%] $(10 \%$ loaded) & $80 \sim 87$ & $79 \sim 85$ & $90 \sim 92$ & $91 \sim 93$ & $78 \sim 86$ \\
\hline max. rotation speed $\left[\mathrm{min}^{-1}\right]$ & $4,000 \sim 6,000$ & $9,000 \sim 15,000$ & $4,000 \sim 10,000$ & $9,000 \sim 12,000$ & $<15,000$ \\
\hline cost/output $[\$ / \mathrm{kW}]$ & 10 & $8 \sim 12$ & $10 \sim 15$ & $9 \sim 13$ & $6 \sim 10$ \\
\hline cost of controller & 1 & 3.5 & 2.5 & 2.5 & 4.5 \\
\hline durability & good & excellent & good & excellent & good \\
\hline reliability & fair & excellent & good & excellent & good \\
\hline
\end{tabular}




\section{1 小型・高性能化の推移}

サーボモータは, 半導体製造機器, 実装機, 各種産業用 ロボット，金属加工機などに適用されている.サーボモー タの製品例を Fig.3 に示す .サーボモータには , 以下の特 性が要求される.

(1) 小型·軽量化 (機器の小型化, 可動部の動作速度向上)

(2) 高パワーレート化 (機器の高速位置決め)

(3) 低コギングトルク化 (機器の低トルクリプル)

Fig.4 に, サーボモータの重量と定格パワーレート密度 の推移 (200 W 級) を示した .ここで, 定格パワーレート は，「モータ単体を定格卜ルクで加速したとき，モータが 発生する出力速度」と定義され，加減速性能を示す動的な 操作性能值である.高パワーレート化は, モータの急加減

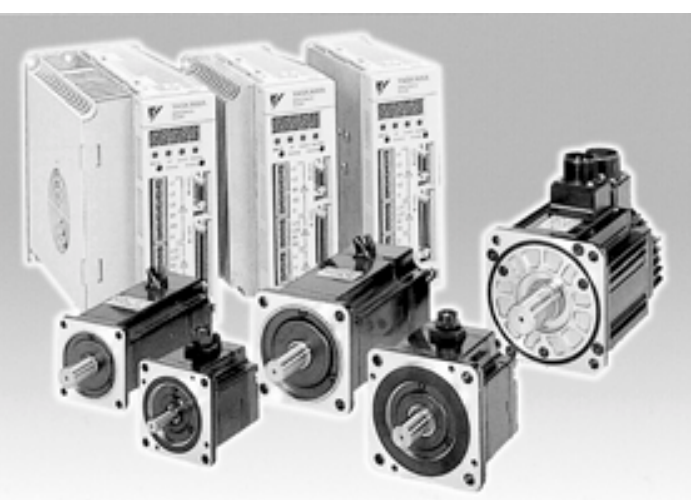

Fig.3. Servo motors(Sigma series).

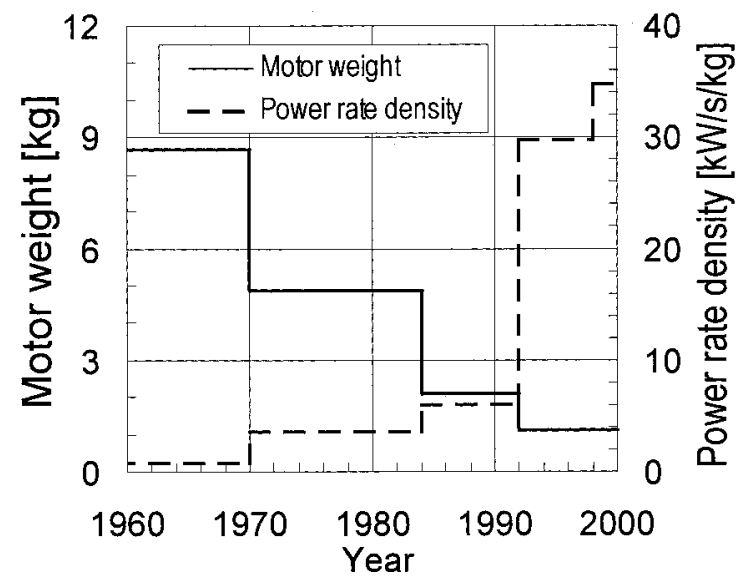

Fig.4. Change in motor weight and power rate density.
速を可能とし，機器の高速位置決めを実現できる .

Table 2 に新旧のサーボモータの特性を比較したが , パ ワーレート密度が約 50 倍, 重量が $1 / 7$, 体積が $1 / 9$ と, 大 幅な小型・高性能化が実現されている .

永久磁石の最大エネルギー積の推移を Fig.5 に示した . 永久磁石の高性能化はサーボモータの小型·軽量化と強い 相関関係があるが,他に巻線技術や冷却技術の向上も重要 な役割を果たしている。

\section{2 小型・高性能化技術}

サーボモータの小型・高性能化は, 電気装荷向上, 磁気 装荷向上, 冷却改善により実現された ${ }^{5)}$. モータの大きさ は, 内部で発生する熱に制約される.光こで，モータの小 型化のためには, 発生熱の低減と発生熱の有効な冷却が必 要となる. 高パワーレート化のためには, モータイナー シャの低減が必要であるが, モ一タの小型・軽量化により 必然的に実現できる.さらに，高性能永久磁石の適用によ り磁石使用量を低減させることも有効である .

従来のサーボモータの巻線は, 固定子コアのスロット開 口部から行っていたため巻線量に制約があり，乥のスペー スファクタ (スロット断面積に対する巻線断面積の割合) は $40 \%$ 程度であった . 乥こで, 固定子コアを分割するこ とにより，俵積みに完全整列巻線が可能となり，スペース ファクタを $70 \%$ まで高めることができた . 結果 , 巻数を 変えることなく巻線を太くでき, 巻線抵抗低減 $=$ 銅損低減

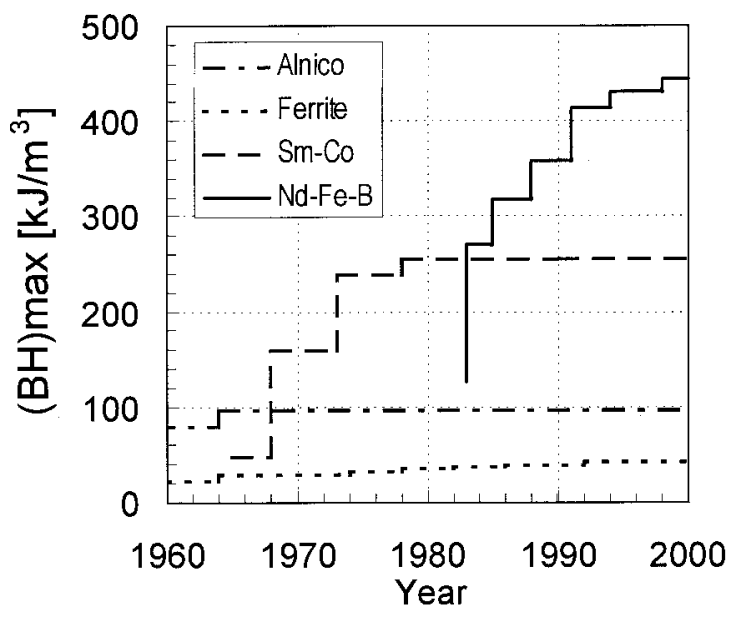

Fig.5. Change in maximum energy product of various magnets.

Table 2. Change in servo motor specification.

\begin{tabular}{c|c|c|c}
\hline & DC servo (1959) & AC servo (1998) & Ratio (1959 to 1998) \\
\hline rated output $[\mathrm{kW}]$ & 185 & 200 & - \\
\hline power rate $[\mathrm{W} / \mathrm{s}]$ & 6.1 & 38.2 & 6.3 \\
\hline power rate density $[\mathrm{W} / \mathrm{s}) / \mathrm{kg}]$ & 0.76 & 35 & 46 \\
\hline flange size $[\mathrm{mm}]$ & 130 & 80 & 0.62 \\
\hline weight $[\mathrm{kg}]$ & 8.0 & 1.1 & 0.14 \\
\hline volume $10^{-3}\left[\mathrm{~m}^{3}\right]$ & 3.1 & 0.35 & 0.11 \\
\hline
\end{tabular}


を可能にした .

巻線からの発生熱の放熱性改善のため,スロット内部お よび巻線端に熱伝導性の良い熱硬化性樹脂をモールドし た.結果，熱遮断されていた巻線と絶縁部間およびコアと 絶縁部間の熱伝達が良くなり，冷却効率を改善できた．

以上の高密度巻線による銅損低減とモールドによる冷 却効率改善により，電気装荷を向上させた．

モータの小型化により永久磁石の寸法が制約されるが， 高性能永久磁石はこの制約を補うだけでなく，さらなる磁 気装荷の向上を可能にした．

コギングトルクは,ギャップ中のエネルギーの変化に起 因し ,ギャップ中の磁束密度の二乗の総和に比例する . 永 久磁石の高性能化は,モータの小型化や高パワーレート化 には有効であるが，コギングトルクを増大させてしまう． そこで, スキューや分数スロット, 内つなぎコア構造の採 用により,ギャップ中の磁束密度の変動を抑制した.さら に磁界解析の活用により, 磁石の形状や磁気回路, 着磁条 件などを最適化し，コギングトルクを低減させた ${ }^{6}$.

\section{3 超小型化技術}

ノート型パーソナルコンピュータや携帯情報機器 $(P D A)$, 携帯電話の小型・薄型化は, 光れらを組み立てる 電子部品実装機に搭載するサーボモータのさらなる小型 化を要求する. 高性能永久磁石によるモータの小型化, お よび半導体部品の小型化と実装技術の高密度化により， モータおよびエンコーダの小型化が可能となった .

Fig.6 に超小型サーボモータの製品例を示す.サーボ モータの定格出力とモータ体積の関係を Fig.7 に示した . Fig.8に同一外径のサーボモータ $(10 \mathrm{~W})$ とステッピング モータのトルク曲線を示した . 超小型サーボモータは, ス テッピングモータと比べて高トルクであるだけでなく，高 速回転を実現しており,搭載した機器の高速化を可能とし た ${ }^{7}$.

\section{4 大容量化技術}

従来, 数十 $\mathrm{kW}$ といった大容量の駆動には, 油圧サーボ

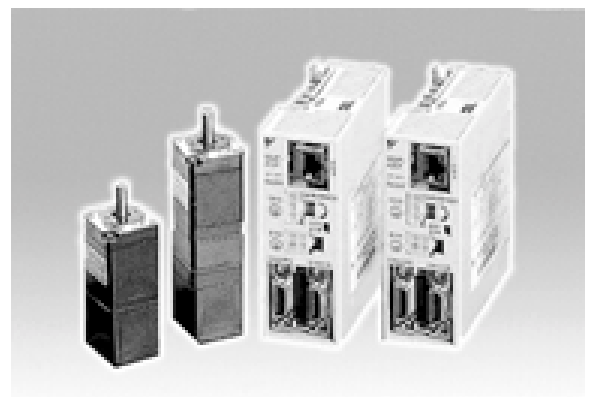

Fig.6. Ultra-small-sized servo motors(Sigma-mini series).

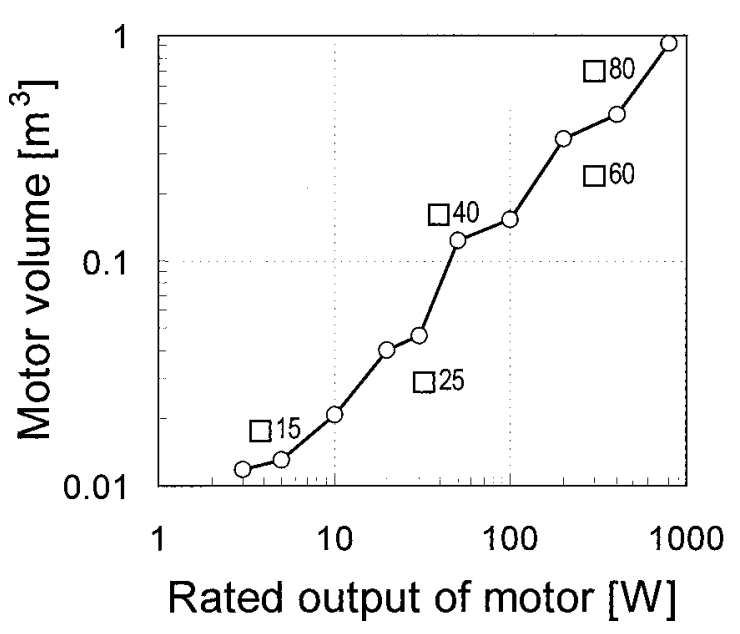

Fig.7. Change in motor volume with the rated output of servo motor.

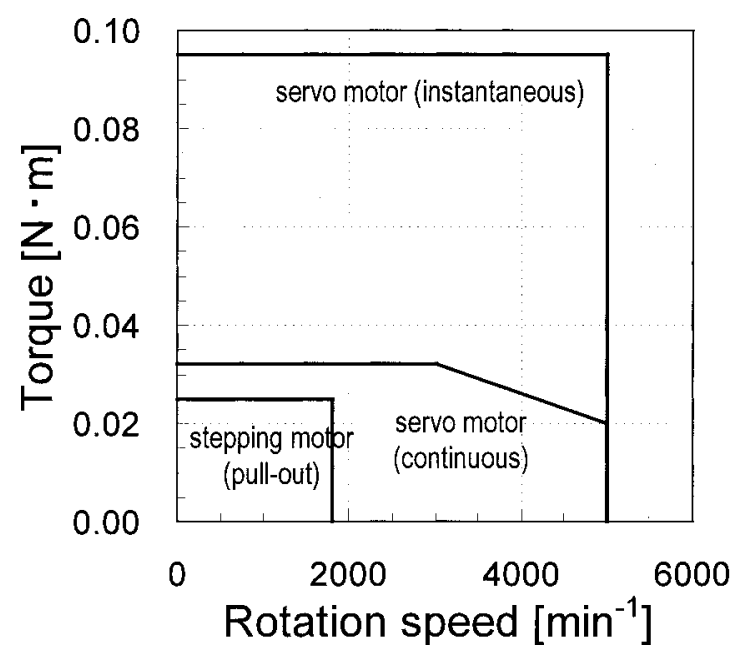

Fig.8. Torque curves of servo motor and stepping motor.

が多く使われてきた .しかし, 最近の環境への配慮やマシ ンの小型化・取り扱いやすさから, 大容量サーボモータが 射出成形機や大型のロボット, 液晶用スピンコータなどに 採用されている.

SPM 構造を大容量サーボモータに適用すると，インダ クタンスが小さくなりすぎ, 電流リプルの増大により磁石 表面の渦電流損失が増大し，制御性が悪化するため，好ま しくない、採用した IPM 構造は適度なインダクタンスを 発生するため, 電流リプルは小さく, 永久磁石がコアの内 側にあることから永久磁石表面の渦電流損失も低減でき， 耐遠心力の面からも優れている.さらに,リラクタンスト ルクを有効活用することにより, 永久磁石量を低減できた 8),9).

Fig.9 に大容量サーボモータの製品例を示した . 大容量 サーボモータの用途は, 輪転機や自動倉庫などの一般産業 
機械分野にも広がりつつある．

\section{4 . 永久磁石モータの応用}

永久磁石モータの応用例として,ポンプ, エレベータ巻 上機，射出成形機，産業用ロボットを取り上げ説明する。

\section{1 ポンプ}

ファン,ポンプなどの風水力機械やコンベヤ, 昇降機な どの搬送機械などには，従来は電源周波数に準じた速度で 駆動する誘導モータが用いられてきたが,省エネルギーを 指向した汎用インバータと大型永久磁石モータによる可 変速システムが増加している．

サーボドライブが高速・高精度位置決め, 同期制御に適 しているのに対し，インバータ駆動の可変速ドライブは省 エネルギー, 可変速運転に適している

可変速ドライブの製品例を Fig.10 に示した.ポンプな どに用いる可変速システム用モータには，以下の性能が要 求される.

(1) 高効率 (適用機器の省エネルギー)

(2) 小型・軽量化 (適用機器の小型・軽量化)

Table 3 に示したように, 永久磁石モータは, 誘導モ一 タと比較して損失を低減し，小型・軽量化を実現できる。

ポンプに適用した事例 ${ }^{10)}$ をFig.11に示した . 従来の誘 導モータの商用電源駆動 (一定速運転) のバルブ制御 (IM+valve, $75 \%$ 流量時の損失 : $2.6 \mathrm{~kW})$ と比較すると，イ

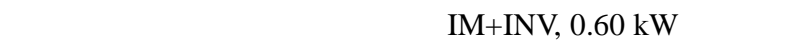
を大幅に低減でき，IPM モータ (IPMSM+INV, $0.43 \mathrm{~kW}$ )

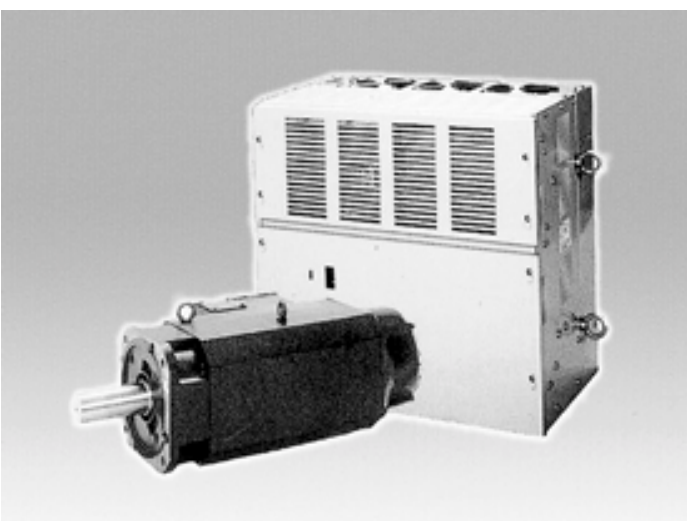

Fig.9. Large torque servo motor(Sigma series).
では省エネルギー効果がさらに大きくなることが分かる． 永久磁石モータの適用による省エネルギ一効果は, 環境 保全だけでなく経費削減にもつながる。

\section{2 エレベータ巻上機}

高齢者，身体障害者等の公共交通機関を利用した移動の 利便性・安全性の向上を促進するため，2000 年 11 月 15 日に「交通バリアフリー法」が施行され，旅客設備などへ のエレベータの設置が急増している.エレベータ巻上機用

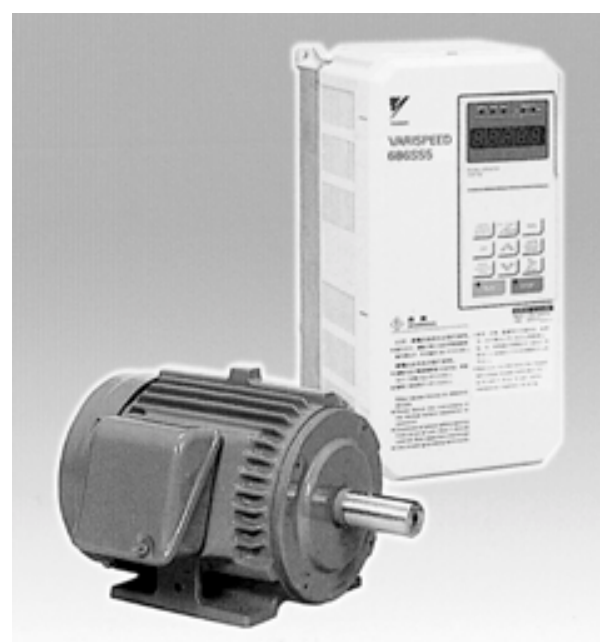

Fig.10. Variable speed drive motor(VS-686SS5).

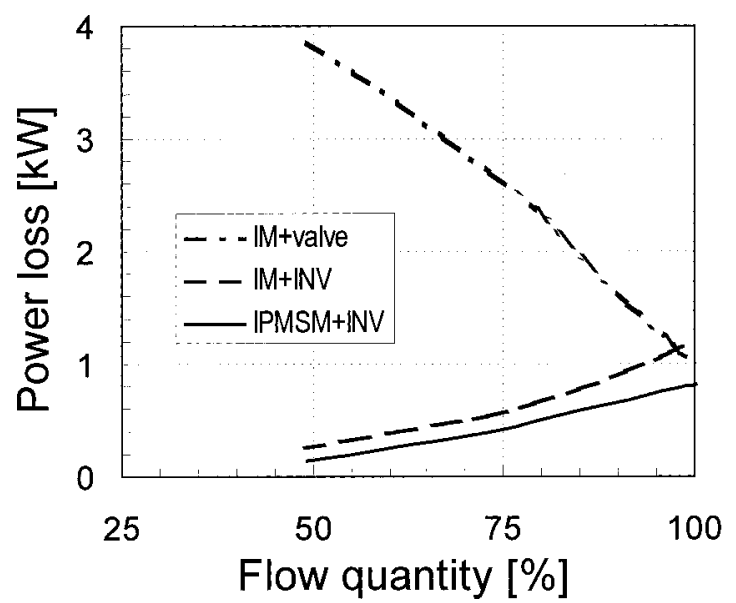

Fig.11. Change in motor power loss with different motors and drives.

Table 3. Motor specification of IM and IPM motor.

\begin{tabular}{c|c|c|c}
\hline & IM & IPMSM & Ratio (IM to IPMSM) \\
\hline output $[\mathrm{kW}]$ & 55 & 55 & - \\
\hline power loss $[\mathrm{kW}]$ & 8.3 & 5.3 & 0.64 \\
\hline efficiency $[\%]$ & 86.9 & 91.2 & 1.05 \\
\hline weight $[\mathrm{kg}]$ & 330 & 173 & 0.52 \\
\hline volume $\left[\mathrm{m}^{3}\right]$ & 0.058 & 0.032 & 0.55 \\
\hline
\end{tabular}


モータとしては, 従来の直流モータや誘導モータが用いら れてきたが, 最近になりインバータ駆動の永久磁石モータ が採用され，急速に普及し始めている.エレベータ巻上機 用モータとしては, 以下の性能が要求される .

(1) 高効率 (エレベータの省エネルギー)

(2) 小型・軽量・薄型 (エレベータの設計自由度拡大)

(3) 低振動・低騒音 (エレベータの乗り心地改善)

エレベータには,乗り心地の観点から駆動系にギアがな いギアレス巻上機が一般的に用いられている ${ }^{11)}$. ギアレ ス化のためにはモータの多極化が必要であるが, 従来の誘 導モータでは, 極数増加にともない力率が低下するため， 8 極程度か限界であった .これに対し, 永久磁石モータで は, 極数に関係なく高力率・高効率駆動が可能であるの で,多極化 (20 極以上) によるギアレス化か実現できた 。 さらに,多極化は,鉄心外径の縮小やコイルエンド長の短 縮にもつながり，モータの小型化・薄型化にも貢献してい る。

Fig.12に機械室レスエレベータの概略図を示した 小型 化された巻上機および制御盤を昇降路内に配置すること により，機械室をなくすことができた．結果，エレベータ 設置の自由度が大幅に拡大し，建物を有効活用できるよう になった .次世代機械室レスエレベータでは,Fig.13のよ うにモータを薄型化 ${ }^{12)}$ することにより，乗りかごと昇降 路壁面の間に巻上機用モータを設置できるようになり， いっ弚うの省スペース化が実現できている。

\section{3 射出成形機}

射出成形機は樹脂成形機のひとつで, 溶融させた樹脂を 金型に充填させ，加圧，冷却し，取り出すことによって樹 脂成形体を製造する機械である. 射出成形機は, 数〜数十 $\mathrm{kW}$ 以上の大きなサーボ出力を要求することから，従来は 油圧サーボが多用されていた。近年, 永久磁石の高性能化 によりサーボモータが大容量化したので,省エネルギーや 環境性能に優れた電動式射出成形機が普及している.

Fig.14に射出成形機の模式图を示す.射出成形機は，材 料を可塑化計量する可塑化軸，材料を金型へ押し出す射出 軸, 材料を一定力て締め付ける型締め軸, 成形品を金型か ら取り外す突出軸からなる.電動式射出成形機では, 完全 に電動化した場合には 4 軸にサーボモータを搭載し,直圧 方式で型開閉動作と型締め動作に用いるサーボモータを 分ける場合には 5 軸となる ${ }^{8), 9)}$.

射出成形機用サーボモータの製品例をFig.15に示した。 射出成形機用モータには, 以下の性能が要求される.

(1) 大容量化 (電動式の大型化)

(2) 高効率化 (省エネルギー)

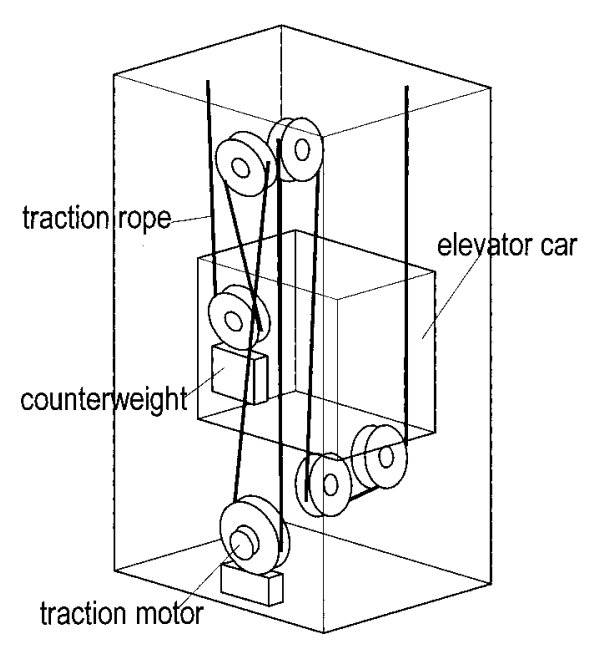

Fig.12. Elevator without a machine room.

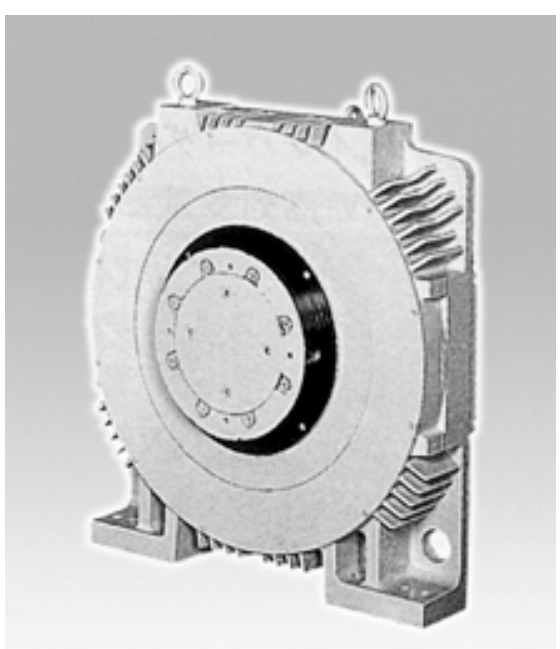

Fig.13. Flat-shaped traction motor for elevator.

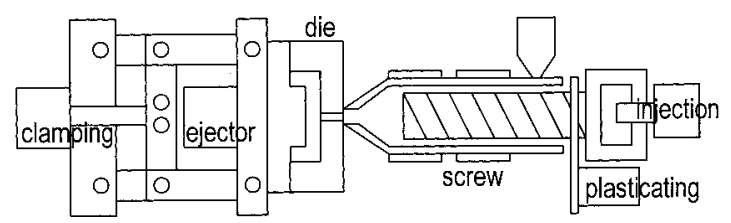

Fig.14. Schematic figure of injection molding machine.

電動式射出成形機は, 従来の油圧式射出成形機と比較す ると, 省エネルギー (電力消費量が $1 / 3 \sim 1 / 5$ 以下), 生産 性向上 (サイクルタイムが 4 割前後短縮), 成形品の高品 位化 (高精密, 薄型化)，作業環境改善 (加工時に潤滑油 を使用しない）といった特長を有する．

型締め力 $15 \sim 300$ トンの小型電動式射出成形機は, 携 帯電話やデジタルカメラの部品, コンパクトディスクケー ス,コネクタなどの成形加工向けとして多く使用されてい 


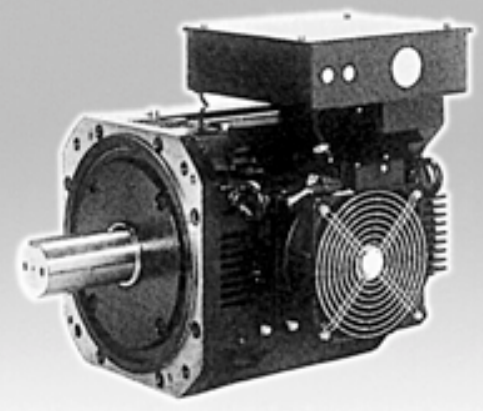

Fig.15. Servo motor for injection molding machine(Sigma series).

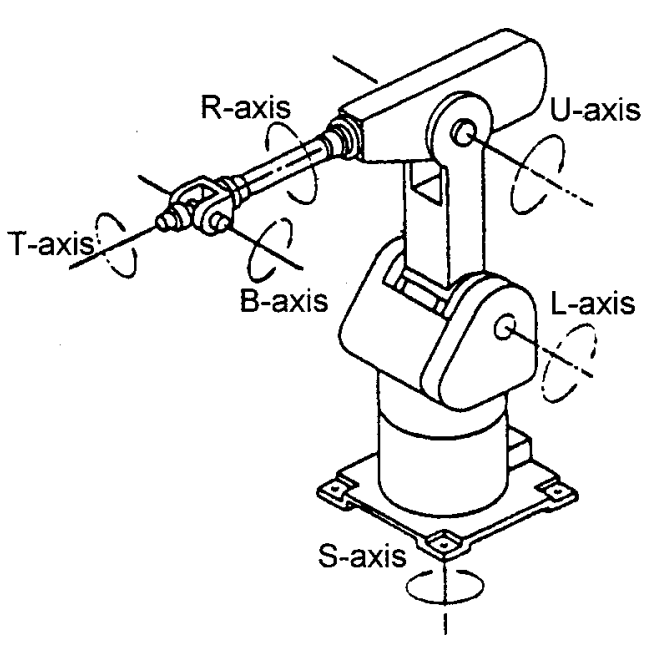

Fig.16. 6-axis vertical multi-joint robot.

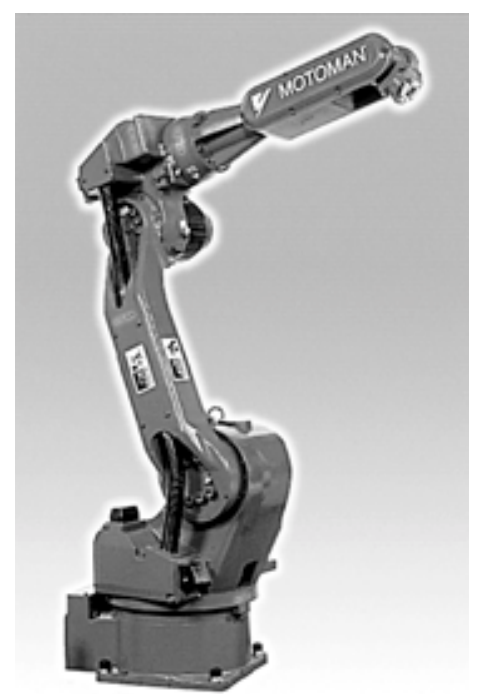

Fig.17. Industrial robot for arc welding(MOTOMAN-UP6).
る.サーボモータのさらなる大容量化により,型締め力が 1000 卜ンを越える電動式射出成形機も登場している.

4.4 産業用ロボット

産業用ロボット (以下ロボットと略す) は, 作業の自動 化の手段として生産ラインに導入されてきたが, 兴の役割 は,自動化からコストミニマムを追求した生産手段へと変 化している.ロボットには, 高い生産性や付加価值の追 求, 省スペース, 稼働率の向上が要求されている.

6 軸垂直多関節ロボット ${ }^{13)}$ について説明する.Fig.16 に示したように, 旋回 ( $\mathrm{S}$ 軸), 下腕傾動 ( $L$ 軸), 上腕 傾動 ( $U$ 軸), 手首旋回 ( $R$ 軸), 手首振り ( $B$ 軸), 手 首回転 ( $\mathrm{T}$ 軸) の 6 個のサーボモータガ搭載されている. 各軸の最大動作範囲は $240 \sim 400^{\circ}$ 程度であり, サーボ モータには減速機を付けている.

アーク溶接用6軸垂直多関節ロボットの製品例をFig.17 に示した .ロボット用モータには, 以下の性能が要求され る。

(1) 小型・軽量 (高速化, 下部軸の負荷軽減)

(2) 耐振動・衝撃性 (先端軸の高速での加減速動作)

アーク溶接以外にも, スポット溶接, 組み立て, ワーク ハンドリング , パレタイズ， シーリング，検査などへと， ロボットの適用範囲は広がっている .

\section{5 .おわりに}

高性能で安価な永久磁石の登場は, 永久磁石モータの小 型・高性能・高効率化を可能とし, 適用機器の高性能・高 機能化や小型・軽量化, 省エネルギーを実現してきた.永 久磁石の高性能化に加えて,今後は磁石特性のバラツキ抑 制のための品質管理および減磁や耐食性などの信頼性確 保が，いっ光う期待される。

\section{(文 献)}

1)石橋: 電気学会マグネティックス研究会資料, MAG-01181(2001).

2)武田:第3回マグネットセミナー, (1998), 37.

3)大山: 電気学会論文誌 $D, 118(1998), 813$.

4)石橋他: 電気学会マグネティックス研究会資料, MAG01-54(2001).

5)熊田 他: 安川電機, 56(1992), 114.

6)熊田 他:安川電機, 62(1998), 226.

7)吉田 他: 安川電機, 62(1998), 247.

8)長井他: 安川電機, 62(1998), 243.

9)吉田 他: 安川電機, 65(2001), 314. 
10)永木 他: 安川電機, 62(1998), 283.

11)須藤: 電気学会誌, 119(1999), 516.

12)安川電機, 66 (2002), 17 .

13)松崎: オートメーション, 40(1995), 42. 